\title{
Influence of graduation towers in Inowrocław Spa Park (Poland) on chemical parameters of Mollic Gleysols
}

\author{
Magdalena Krzyżaniak-Sitarz \\ Department of Environmental Development and Protection, \\ University of Technology and Life Sciences, Sucha 7, 85-791 Bydgoszcz \\ email:sitmag@wp.pl
}

\begin{abstract}
Summary. Calcium was the dominant element in the sorption complex of the analysed soils, regardless of the location of a soil profile. Moreover, in most of the endopedons, the concentration of $\mathrm{Ca}^{2+}$ was two or even three times higher than in non-saline soils, which were not affected by anthropopressure. One should, however, emphasize the fact that graduation towers are significant but not the dominant source of calcium in the analysed soil profiles. The concentration of $\mathrm{Ca}^{2+}$ is also strongly affected by the vicinity of the urban area and lime plants, as well as by the composition of the parent rock. The soils of the Spa Park in the town of Inowrocław are Mollic Gleysols with the elevated content of sodium, which together with a small amount of atmospheric precipitation and a constant inflow of sodium from the graduation towers, can bring about negative changes in their physical properties and the composition of the sorption complex. This negative influence of sodium cations can be counterbalanced by a high content of calcium ions. Among water-soluble anions, chloride anions had the highest concentration. The concentration of $\mathrm{Cl}^{-}$in the aqueous soil solution was increasing together with the depth of profiles and was significantly decreasing with the increasing distance from the graduation towers. Moreover, in the profiles located near the graduation towers, the concentration of chlorides in all soil horizons was higher than the permissible limit of $10 \mathrm{mg} \cdot 100 \mathrm{~g}^{-1}$.
\end{abstract}

Key words: anthropopressure, graduation towers, soil salinity.

\section{Introduction}

The soils of the Spa Park in Inowrocław, as most of the soils of the Inowrocław Plain, belong to one of the largest Mollic Gleysols complexes in Poland. Due to its location and agricultural suitability, the area of Mollic Gleysols in Kuyavia is exposed to considerable human impact, the consequence of which are changes in physicochemical soil properties. The most spectacular phenomenon of degradation of these soils is the salinity process. In Poland, natural salinity has a limited range and therefore the human activity is thought to be the main cause of that phenomenon, especially through the impact of sodium and mining industries, soil irrigation with sewage, application of min- eral fertilizers and anti-slippery products on traffic routes (Hulisz 2007). Graduation towers are the unique factor occurring in the Spa Park in Inowrocław and locally affecting the soils. The constant inflow of large amounts of cations and anions may consequently lead to permanent changes in chemical properties of the soils from the immediate surroundings of the graduation towers.

The objective of this research was to define the impact of graduation towers on the variability in the composition of the sorption complex and the soil solution in the soils of the Inowrocław Spa Park. 


\section{The study area and research methods}

The research area covers almost 60 hectares of the Spa Park in Inowrocław. In the Park area, 7 soil test pits were made (Fig. 1), three times a year (spring, summer, autumn). From each of the genetic horizons of soil profiles, samples were collected for laboratory analyses. Analyses were performed in the extract - soil-water dilution 1:5. With the methods generally accepted in the soil science, the following soil parameters were determined: exchangeable cations - $\mathrm{Ca}^{2+}, \mathrm{Na}^{+}$and water-soluble ions, soil sorption capacity, the content $\mathrm{Cl}^{-}, \mathrm{HCO}_{3}{ }^{-}$and $\mathrm{SO}_{4}{ }^{2-}$ (van Reeuwijk 2002). Results of the inhaled air quality measurements performed near the brine graduation towers and collected in the study of the National Hygiene Institute in Poznań, indicate that sodium chloride is the dominant compound in the aerosol produced by the graduation towers $\left(0.8-96 \mathrm{mg} \cdot \mathrm{m}^{-3}\right)$. The content of sodium chloride is diversified and depends on the distance from the graduation towers and the altitude (Latour et al. 2004).

\section{Results and discussion}

On the basis of the previous results published by KrzyżaniakSitarz (2008), the soils of the Spa Park in Inowrocław were classified as Mollic Gleysols. The analysis of the content of particular cations in the sorption complex revealed the dominance of calcium ions (91.4-333 $\left.\mathrm{mmol} \cdot \mathrm{kg}^{-1}\right)$. In profiles 1 and 7, the quantitative predominance of $\mathrm{Ca}^{2+}$ was determined in the horizon of humus accumulation, while in profiles 2, 3, 4 and 5, accumulation of calcium ions was observed in the parent rock. According to the research published by (Cieśla 1961), the content of calcium cations in non-saline Mollic Gleysols of the Kuyavia region ranged from 61 to $120 \mathrm{mmol} \cdot \mathrm{kg}^{-1}$. Whereas in the soils investigated by Rytelewski et al. $(1986,1988)$ and Czerwiński et al. (1984), affected by the sodium industry, the concentration of this chemical element was of the order of one hundred and several tens $\mathrm{mmol} \cdot \mathrm{kg}^{-1}$. Sodium was the second most abundant cation in the soil sorption complex (16.3-73.5 mmol $\cdot \mathrm{kg}^{-1}$ ). In profiles $1,2,4,5$ and 6 , the accumulation of these cations was observed in the parent rock, whereas

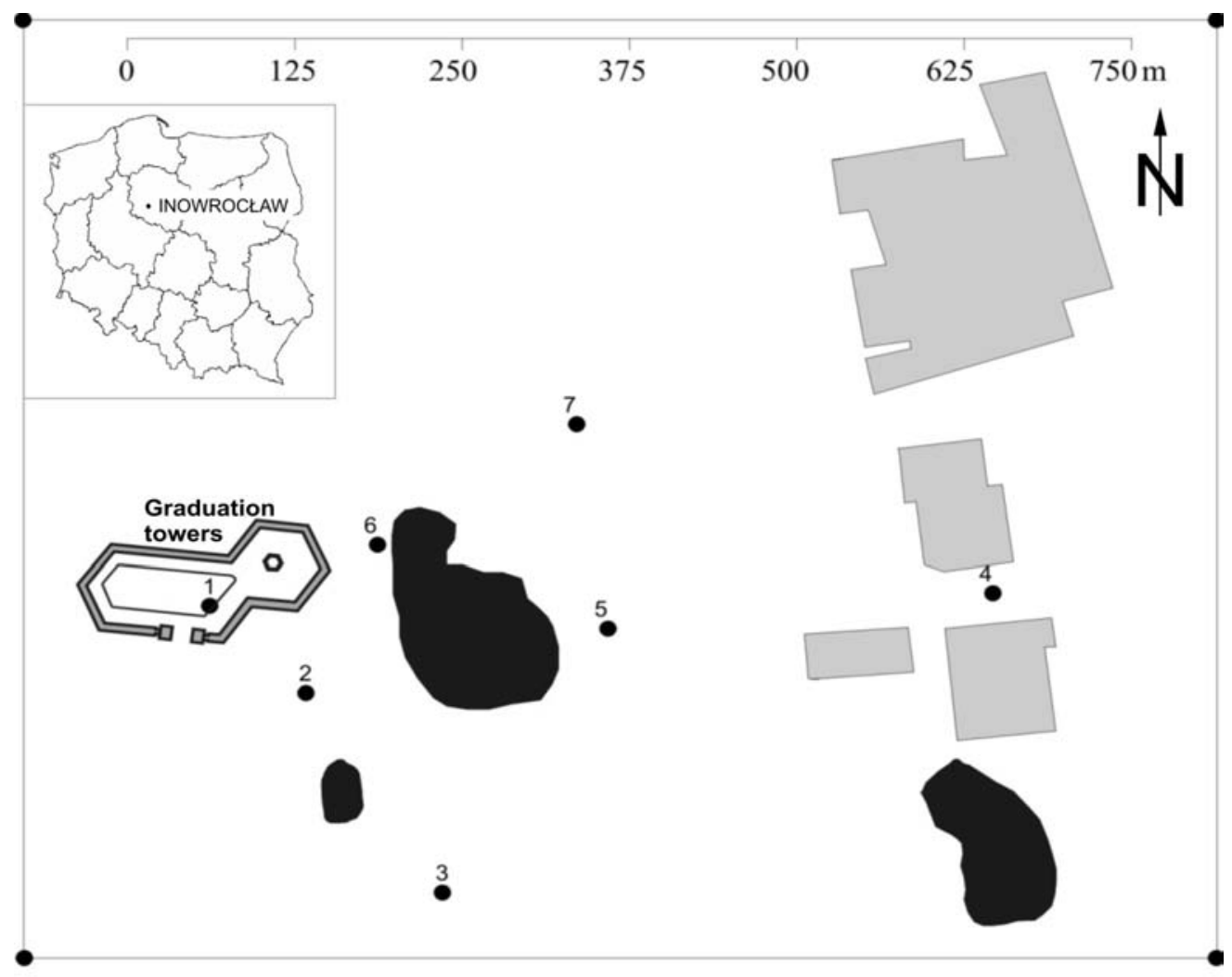

- soil profiles ponds $\square$ buildings

Figure 1. Location of soil profiles in Inowrocław Spa Park 
in profiles 3 and 7 - in the surface horizon. The detailed research on the chemical composition of Mollic Gleysols of the Kuyavia region, conducted by Cieśla (1961) in the 1960s, confirmed that the content of exchangeable sodium cations reached the level of $3-8 \mathrm{mmol}{ }_{\mathrm{c}} \mathrm{kg}^{-1}$. Subsequent analyses of soils affected by anthropopressure, particularly by the sodium industry, proved that the content of $\mathrm{Na}^{+}$reached $120-130 \mathrm{mmol} \cdot \mathrm{kg}^{-1}$ in places recently flooded by the contamination source (Rytelewski et al.1986, 1988; Hulisz 2003). Sodium cations had the highest concentration among cations in the soil solution of the analysed profiles $\left(0.69-42.5 \mathrm{mmol} \cdot \mathrm{kg}^{-1}\right)$. Moreover in profiles no. 1,2 , 4, 5 and 6 , the concentration of water-soluble sodium was increasing together with the increasing depth. The research revealed that the amount of water-soluble $\mathrm{Na}^{+}$in several soil horizons was much higher than the concentrations characteristics of non-saline Mollic Gleysols of the Kuyavia region, where it averaged at $7 \mathrm{mmol} \cdot \mathrm{kg}^{-1}$ (Kwasowski 1996). On the other hand, it was lower than the concentration of water-soluble sodium in soils under the influence of the sodium industry, which was up to $65-100 \mathrm{mmol}_{\mathrm{c}} \mathrm{kg}^{-1}$ (Rytelewski et al. 1988). The concentration of water-soluble calcium cations ranged from 0.05 to $9.43 \mathrm{mmol} \cdot \mathrm{kg}^{-1}$. In soil profiles no. 2, 3 and 6 , the highest concentration of these cations was observed in the parent rock. Among water soluble anions, chloride anions $\left(2.53-39.4 \mathrm{mmol} \cdot \mathrm{kg}^{-1}\right)$ and bicarbonate anions $\left(0.00-15.1 \mathrm{mmol}_{\mathrm{c}} \cdot \mathrm{kg}^{-1}\right)$ dominated, and to a lesser extent - sulphate anions (0.06-4.67 $\left.\mathrm{mmol} \cdot \mathrm{kg}^{-1}\right)$. Soil profiles no. 1,5 and 6 were characterized by significantly higher concentration of chlorides in the parent rock. Whereas anions $\mathrm{HCO}_{3}^{-}$and $\mathrm{SO}_{4}{ }^{2-}$ did not reveal any characteristic tendencies in their distribution within particular profiles.

\section{References}

Cieśla W., 1961, Właściwości chemiczne czarnych ziem kujawskich na tle środowiska geograficznego [Chemical properties of chernozems in relation to the geographical environment of the Kuyavia region], Poznańskie Towarzystwo Przyjaciół Nauk, Pr. Kom. Nauk Roln. i Leśnych 8: 4.
Czerwiński Z., Pracz J. \& Piątek A., 1984, Wpływ odpadów z Janikowskich Zakładów Sodowych na tereny rolnicze [Influence of wastes from the Janikowo Soda Works on agricultural areas], Rocz. Glebozn. 35 (3/4): 87-105.

Hulisz P., 2003, Soil salinity in the vicinity of Inowrocław (Poland) due to the effect of soda industry, Abstracts, SUITMA Conference, Nancy: 159-160.

Hulisz P., 2007, Wybrane aspekty badań gleb zasolonych w Polsce [Selected aspects of the research on saline soils in Poland], SOP, Toruń.

Krzyżaniak-Sitarz M., 2008, Wpływ antropopresji na właściwości fizykochemiczne gleb w Parku Zdrojowym w Inowrocławiu [Influence of anthropopressure on physicochemical properties of soils in the Spa Park in Inowroclaw], Ekologia i Technika 16 (4): 181-189.

Kwasowski W., 1996, Zasolenie gleb i skład jonowy soli łatwo rozpuszczalnych w wodzie w rejonie wpływu elektrociepłowni Siekierki [Soil salinity and ionic composition of readily water-soluble salts in the region influenced by CHP Siekierki], Rocz. Glebozn, 47: 145-152.

Latour T., Czajka K., Drobnik M. \& Sziwa D., 2004, Badania mikroklimatu w strefie przytężniowej w Inowrocławiu [Studies on microclimate in the area of Inowroclaw Spa Park], PZH, Zakład Tworzyw Uzdrowiskowych, Poznań.

Rytelewski J., Kasińska D., Poradziński M., Przedwojski R. \& Wróbel R., 1988, Chemizm gleb rozmieszczonych wzdłuż rurociągów solankowych w rejonie Inowrocławia [Chemism of the soils distributed along brine pipelines in the district of Inowrocław], Zesz. Nauk. ART, Olsztyn, Rolnictwo 45: 35-41.

Rytelewski J., Przedwojski R. \& Poradziński M., 1986, Wpływ zakładów chemicznych na zasalanie gleb [Effect of chemical plants on soil salinity], [in:] Problematyka gleb zasolonych na Kujawach w aspekcie ich rekultywacji, Mat. Konferencyjne, Inowrocław 1: 1433.

van Reeuwijk L. P., 2002, Procedures for soil analysis, ISRIC, FAO, sixth edition, Wageningen. 